\title{
Health Benefits of Morinda citrifolia (Noni): A Review
}

\author{
Mohammad Ali, Mruthunjaya Kenganora, Santhepete Nanjundaiah Manjula* \\ Department of Pharmacology, JSS College of Pharmacy, JSS University, Sri Shivarathreeshwara Nagar- 570015, Dist-Mysore, State- Karnataka, INDIA.
}

\begin{abstract}
Background: Morinda citrifolia (Noni) has been used widely as a complementary and alternative therapy in many countries owing to its potent antioxidant activity and proven health benefits. Traditionally, it finds used as a therapeutic remedy to various diseases as an antibacterial, antitumor, anthelminthic, analgesic, anti-inflammatory, immunostimulant. Also it has proved beneficial in conditions like gastritis, skin diseases, respiratory infections, menstrual and urinary tract disorders, fever, diabetes and venereal diseases. Objective: This review emphasizes on the phytochemical and mineral profile of the different parts of Noni plant. In addition, this review corroborates the pharmacological basis for the various health benefits, traditional and medicinal applications of Noni. Materials and Methods: All the available information of Noni were collected from electronic databases such as Academic Journals, Ethnobotany, Ethnopharmacology, Springer, PubMed, Google Scholar, Science Direct and other primary and secondary sources. Results: According to our search results pertaining to scientific literature, Morinda citrifolia is used for more than 40 types of ailments worldwide. Crude extract of various parts of plant and fruit juice are reported
\end{abstract}

to contain amino acids, anthraquinones, fatty acids, flavonoids, iridoids, lignans, polysaccharides, sterols, sugars, terpenoids etc. which are therapeutically useful for a broad range of pathological conditions. Fourteen human clinical trials have validated the remarkable health benefits of Noni. Conclusion: Literatures prove that Noni is pharmacologically active and is used in different forms of cancer, viz. colon, esophageal, breast, colorectal cancers; cardiovascular diseases, diabetes, arthritis, hypertension. These properties are substantiated by the preclinical or/and clinical investigations.

Key words: Morinda citrifolia, Neutraceutical, Phyto-constituents, Antioxidant, Anticancer.

Corresponding author: Santhepete Nanjundaiah Manjula,

Department of Pharmacology, JSS College of Pharmacy, JSS University, Sri Shivarathreeshwara Nagar- 570015, Dist-Mysore, State-Karnataka, INDIA.

Phone No: +91-9916264940

Email: snm.manjula@gmail.com

DOI : $10.5530 /$ pj.2016.4.4

\section{INTRODUCTION}

Morinda citrifolia L. has been recognized as an important herb for treating various physiological disorders worldwide. M. citrifoliais commonly known as Indian mulberry or Noni in India. ${ }^{1}$ Identifiable of this plant are its huge dark green and elliptical glossy leaves (Figure 1); white tubular flowers consisting of 75-90 ovoid to globose heads, 5-lobed white corolla (Figure 2). A yellowish-white ovoid lumpy bodied fruit approximately 12 $\mathrm{cm}$ in size composed of numerous, fused ripened ovaries each separate from white flower. The unripe fruit is dark green in color and the ripe fruit releases a strong butyric acid like decayed smell. The pulp is juicy and bitter, light dull yellowish white, gelatinous when the fruit is ripped; numerous hard triangular reddish brown pits are found (Figure 3 ). ${ }^{2}$ The Noni juice is prepared from ripe Noni fruit which is having unpleasant odour and bitter taste. The fruit is covered with golden-brown pits containing four seeds. Each seed have an air sac at the end, which helps to drift in the water facilitating pollination (Figure 4). ${ }^{3,4}$

Noni plant exhibits a remarkably high therapeutic and safety profile that makes it popular as a health enhancer and food supplement worldwide. ${ }^{5}$ The fruit contains hydrophilic compounds like carbohydrates, proteins, minerals, vitamins and small amount of fat (Table 1). The products obtained from the different parts of $M$. citrifolia plant viz. leaves, fruits, roots and barks are available in the market as Noni juice, capsule, powder, Noni concentrates, and also tea in the market. Among them Noni juice is most popular for its nutraceuticals and high therapeutic values around the globe. Noni juice has been recently established in European Union as a novel food. ${ }^{6}$

Though this review efforts have been made to provide ethnobotanical use, phytochemistry and scientific evidence for the therapeutic potential, discussing the pharmacology at a molecular level and the challenges confronted towards clinical validation of herbal medicines.

\section{Ethnobotanical use}

It has been reported that $M$. citrifolia has wide range of therapeutic uses in ailments such as arthritis, burns, headache, wounds and skin infections. ${ }^{7}$ Polynesian has been cultivated Noni more than 1000 years where it is used as a coloring agent, medicine and food. The root has been used for dyeing agents by the Australians and Indians for various gloom of red, purple and yellow. ${ }^{8}$ Various parts of Noni plant such as stem, bark, root, leaf and fruits are used traditionally by Hawaiians and Tahitians as medicines for the treatment of ailments like cough, cold, pain and liver diseases, hypertension, blood pressure, tuberculosis, malaria, intestinal worms, diabetes, loss of appetite, hernias, urinary tract infection, menstrual disorder, cancer, cardiovascular diseases, arthritis etc. Seeds and its oil applied topically on the scalp as insecticide and used for the treatment of arthritis. Flowers find in application in case of insect stings. In Hawaii, Noni has been reported for topical use in conditions such as swellings, sprains, bruises and wounds. ${ }^{9,10}$

\section{Phytochemistry}

It has been reported that different parts of Noni plant found to contain more than 160 phytoconstituents of which over 120 constituents have nutraceutical properties with proven biological activity. ${ }^{11}$ The concise chemical nature of the plant is given in Table 2. Fermented fruit extract contain micronutrients, non-volatile and volatile components, ketones, lactones, beta-carotenoids, terpenoids, proxeronine. ${ }^{12}$ Physicochemical, phytochemical and antimicrobial properties of Noni fruit collected at different maturity levels were investigated. The results showed the maximum antibacterial activity in ethanolic extract of mature Noni fruit against K. Pneumonia $(21 \mathrm{~mm})$ whereas in methanolic extract of mature Noni fruit showed maximum antifungal activity against A. Flavous $(19 \mathrm{~mm}){ }^{13}$ 


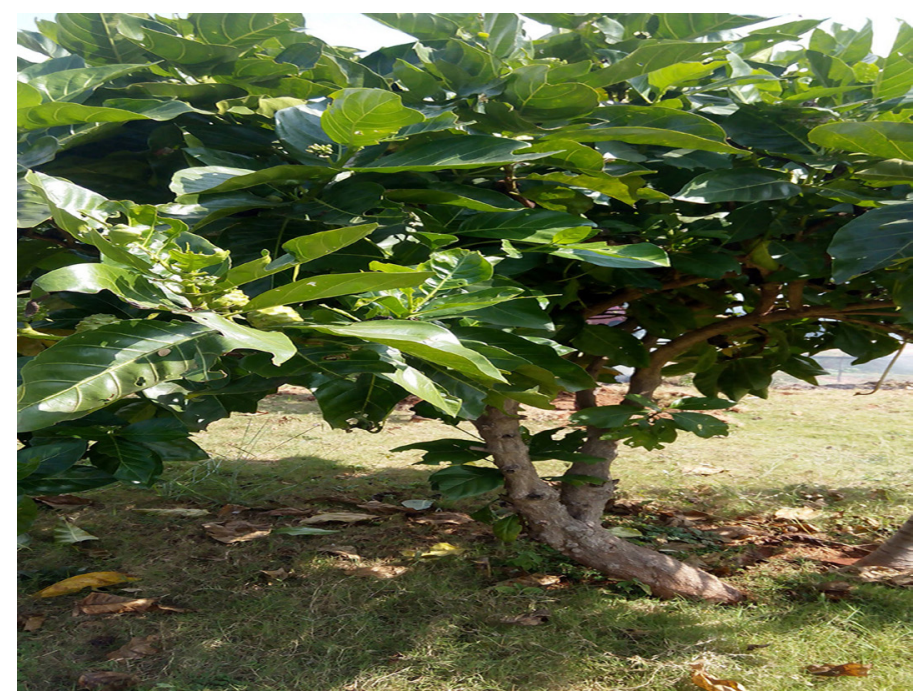

Figure 1: Noni plant.

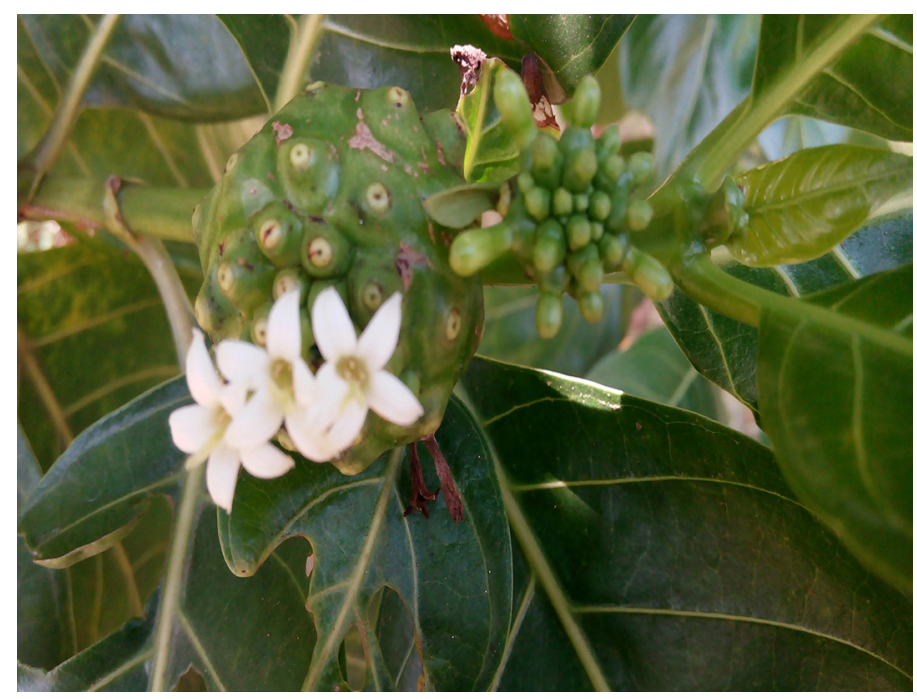

Figure 2: Noni flower.

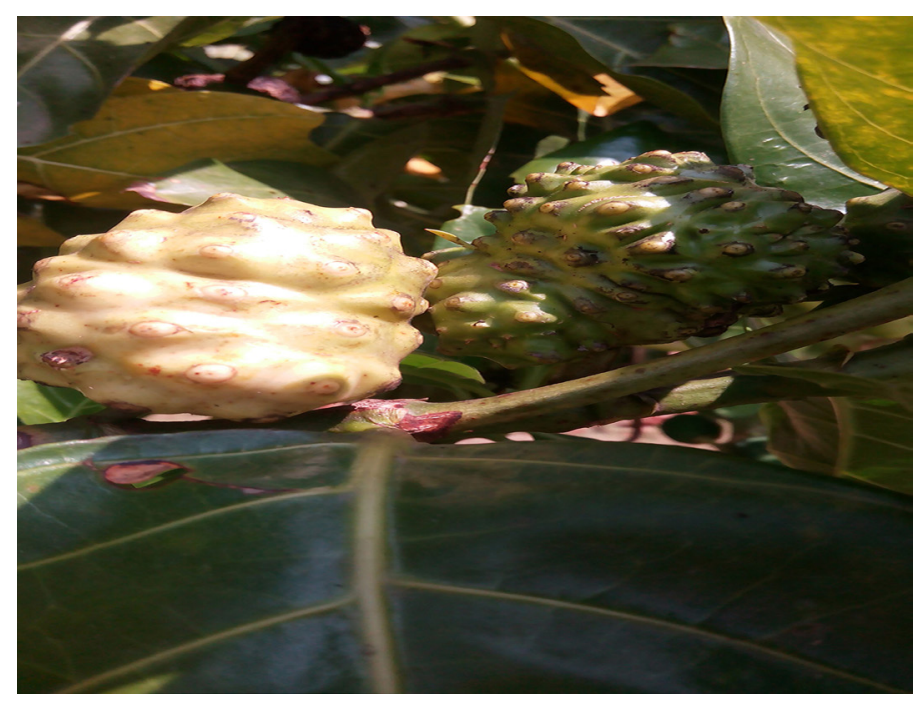

Figure 3: Ripe and unripe fruits.

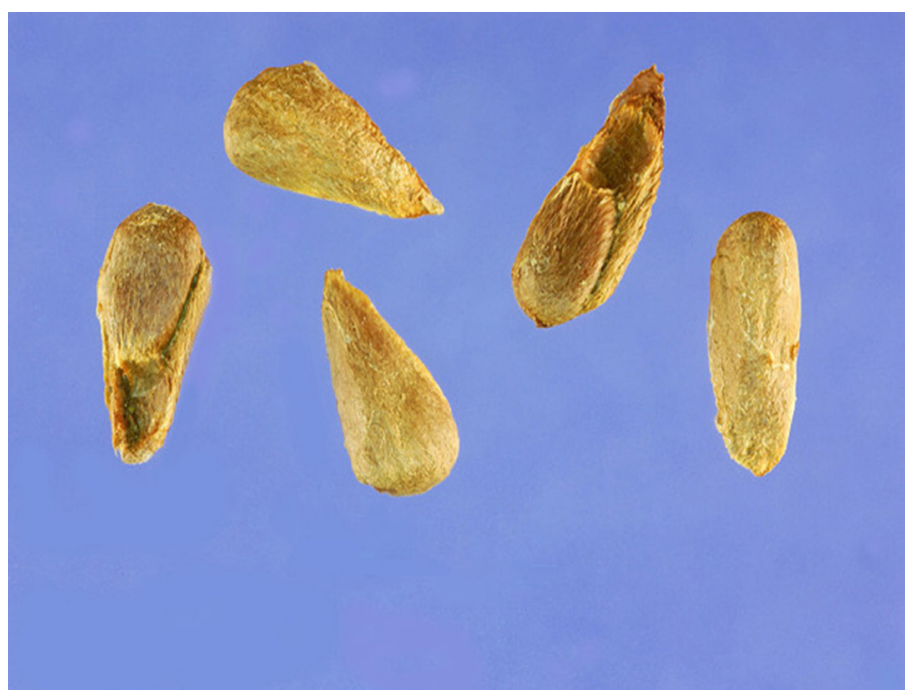

Figure 4: Noni seeds.
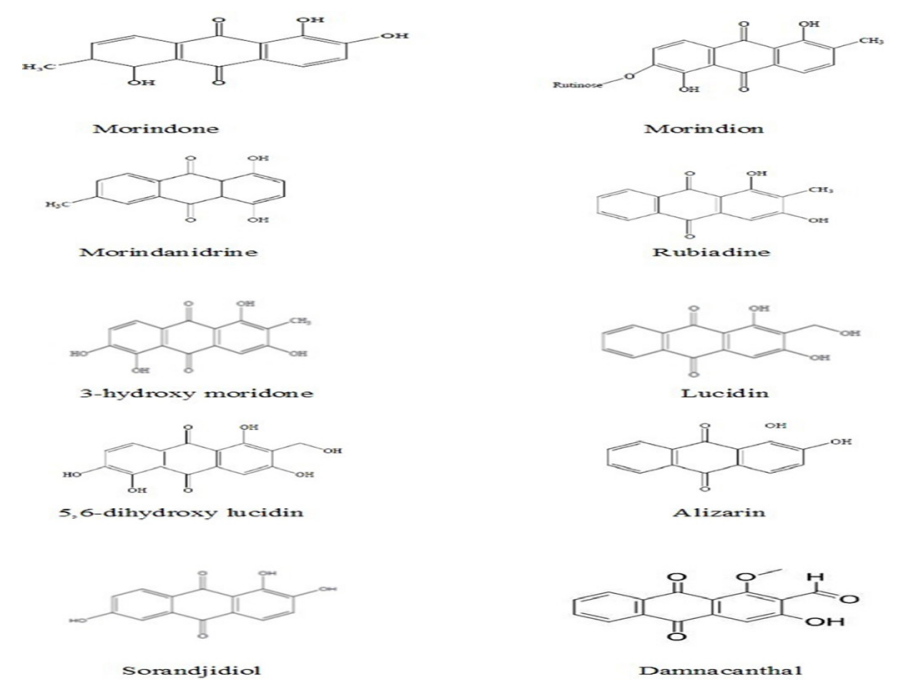

Figure 5: Anthraquinone glycosides. ${ }^{14}$
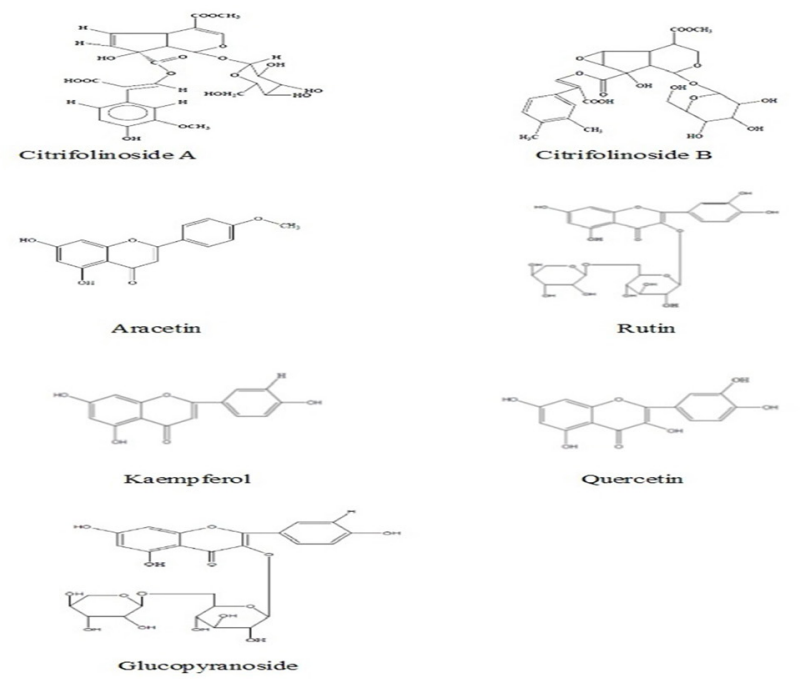

Figure 6: Miscellaneous glycosides. ${ }^{14}$ 


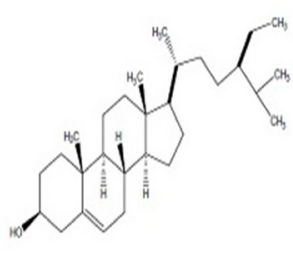

B-Sitosterol

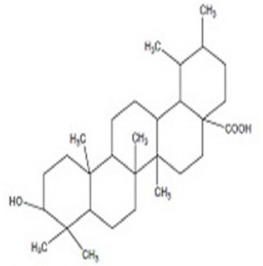

Ursolic acid

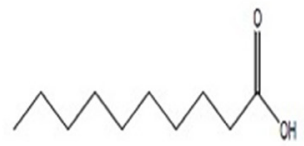

Asperulosidic acid

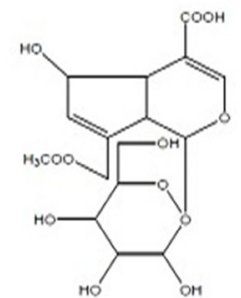

Caproic acid

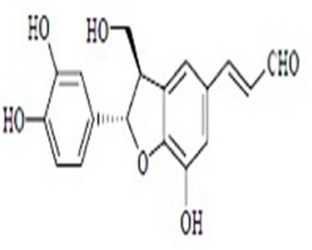

Americanin D

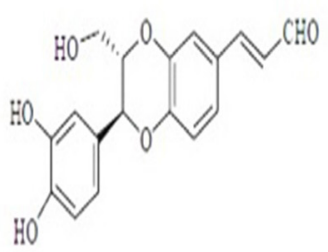

Americanin

Figure 8: Asperulosidic acid, Caproic acid. ${ }^{14}$

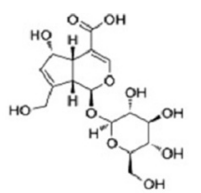

Deacetylasperulosidic acid

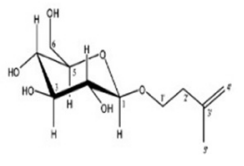

1-O-(3-methylbut-3-enyl)- - -D-glucopyranose 1-n-butyl-4-methyl-2-hydroxysuccinate
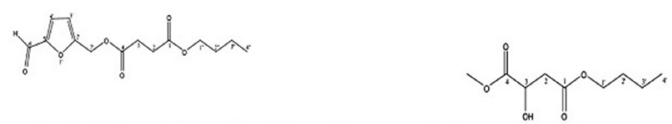

1-n-butyl-4-(5-formyl-2-furanyl) methyl Succinate $\quad$ 1-n-butyl-4-methyl-3-hydroxysuccinate

Figure 9: Deacetylasperulosidic acid, 4-epi-borreriagenin, 1-O-(3-methylbut3-enyl)- $\beta$-D-glucopyranose, 1-n-butyl-4-(5-formyl-2-furanyl) methyl Succinate, 1-n-butyl-4-methyl-2-hydroxysuccinate, 1-n-butyl-4-methyl-3-hydroxysuccinate glycosides. ${ }^{15}$
Figure 10: Ligans. ${ }^{16}$

Table 1: Compositional profile of TNJ101

\begin{tabular}{|c|c|c|}
\hline & Content & Unite \\
\hline \multicolumn{3}{|l|}{ Proximate } \\
\hline Moisture & $89-90$ & $\mathrm{~g} / 100 \mathrm{~g}$ \\
\hline Protein & $0.2-0.5$ & $\mathrm{~g} / 100 \mathrm{~g}$ \\
\hline Ash & $0.2-0.3$ & $g / 100 \mathrm{~g}$ \\
\hline Total fat & $0.1-0.2$ & $g / 100 \mathrm{~g}$ \\
\hline Total carbohydrate & $9.0-11.0$ & $\mathrm{~g} / 100 \mathrm{~g}$ \\
\hline Glucose & $3.0-4.0$ & $\mathrm{~g} / 100 \mathrm{~g}$ \\
\hline Sucrose & $<0.1$ & $g / 100 \mathrm{~g}$ \\
\hline Energy & 163-197 & $\mathrm{kJ} / 100 \mathrm{~g}$ \\
\hline Dietary fiber & $0.5-1.0$ & $g / 100 \mathrm{~g}$ \\
\hline \multicolumn{3}{|l|}{ Vitamin } \\
\hline Vitamin C & $3-25$ & $\mathrm{mg} / 100 \mathrm{~g}$ \\
\hline Vitamin B1 & $0.003-0.01$ & $\mathrm{mg} / 100 \mathrm{~g}$ \\
\hline Vitamin B2 & $0.003-0.01$ & $\mathrm{mg} / 100 \mathrm{~g}$ \\
\hline Vitamin B6 & $0.04-0.13$ & $\mathrm{mg} / 100 \mathrm{~g}$ \\
\hline Vitamin B12 & $0.1-0.3$ & $\mathrm{mcg} / 100 \mathrm{~g}$ \\
\hline Folic acid & $7.0-25.0$ & $\mathrm{mcg} / 100 \mathrm{~g}$ \\
\hline Biotin & $1.5-5.0$ & $\mathrm{mcg} / 100 \mathrm{~g}$ \\
\hline Niacin & $0.1-0.5$ & $\mathrm{mg} / 100 \mathrm{~g}$ \\
\hline Vitamin E & $0.25-1.0$ & $\mathrm{IU} / 100 \mathrm{~g}$ \\
\hline Total carotene & $18-22$ & $\mathrm{IU} / 100 \mathrm{~g}$ \\
\hline Pantothenic acid & $0.15-0.5$ & $\mathrm{mg} / 100 \mathrm{~g}$ \\
\hline \multicolumn{3}{|l|}{ Minerals } \\
\hline Calcium & $20-25$ & $\mathrm{mg} / 100 \mathrm{~g}$ \\
\hline Iron & $0.1-0.3$ & $\mathrm{mg} / 100 \mathrm{~g}$ \\
\hline Phosphorus & $2.0-7.0$ & $\mathrm{mg} / 100 \mathrm{~g}$ \\
\hline Magnesium & $3.0-12$ & $\mathrm{mg} / 100 \mathrm{~g}$ \\
\hline Molybdenum & $0.3-1.0$ & $\mathrm{mg} / 100 \mathrm{~g}$ \\
\hline Sodium & $15.0-40.0$ & $\mathrm{mg} / 100 \mathrm{~g}$ \\
\hline Potassium & $30.0-150$ & $\mathrm{mg} / 100 \mathrm{~g}$ \\
\hline Sodium chloride & $0.09-0.12$ & $\%$ \\
\hline
\end{tabular}


Table 2: Important chemical constituents of Morinda citrifolia along with their locations

\begin{tabular}{|c|c|c|c|c|c|}
\hline \multirow{2}{*}{$\begin{array}{c}\text { Chemical constituent } \\
\text { Anthraquinone }\end{array}$} & \multicolumn{4}{|c|}{ Part of Plant } & \multirow{2}{*}{ Reference } \\
\hline & Frut & Leaf & Root & Plant & \\
\hline Alizarin & + & - & + & - & {$[102][9][103]$} \\
\hline 1,8-dihydroxy-2-methyl-3,7 Dimethoxyanthraquinone & - & - & - & + & [104] \\
\hline Lusidin- $\omega$-butyl ether & - & - & - & + & {$[104]$} \\
\hline 1,3-dihydroxy-2-Methylanthraquinone & - & - & - & + & [104] \\
\hline Trioxymethylanthraquinone monoethyl ether & - & - & + & - & {$[38]$} \\
\hline 2-methyl-3,5,6-trihydroxyanthraquinone & - & - & - & + & [105] \\
\hline Lusidin & - & - & - & + & {$[103]$} \\
\hline 5,6-dihydroxy lucidin & - & - & - & + & [9] \\
\hline 3-hydroxy morindone & - & - & - & + & [9] \\
\hline Morindone & - & - & + & - & {$[4][103][105]$} \\
\hline Damnacanthal & - & - & + & - & {$[75]$} \\
\hline Rubiadinemonomethyl ether & - & - & + & - & {$[4]$} \\
\hline Morindanidrine & - & - & + & - & {$[4]$} \\
\hline Morindadiol & - & - & + & - & {$[4]$} \\
\hline \multicolumn{6}{|l|}{ Glycosides } \\
\hline$\beta$-D-glucopyranoside & - & + & - & - & {$[75]$} \\
\hline Citrofolinin-A & - & + & - & - & {$[102]$} \\
\hline Asperulosidetetraacetate & + & - & - & - & {$[31][106]$} \\
\hline$\beta$-D-galactopyranoside & - & + & - & - & {$[75]$} \\
\hline Kaempferol & - & + & - & - & {$[107]$} \\
\hline Quercetin (Rutin) & - & + & - & - & [107] \\
\hline Citrifolinoside-B & - & + & - & - & [75] \\
\hline \multicolumn{6}{|l|}{ Sterols } \\
\hline$\beta$ - sitosterol & - & + & - & - & [108] \\
\hline \multicolumn{6}{|l|}{ Acids } \\
\hline Caprylic acid & + & - & - & - & {$[4][109][102]$} \\
\hline Caproic acid & + & - & - & - & {$[38]$} \\
\hline Linoleic acid & - & - & - & + & [4] \\
\hline Octanoic acid & + & - & - & - & {$[75][110]$} \\
\hline Hexanoic acid & + & - & - & - & {$[38]$} \\
\hline \multicolumn{6}{|l|}{ Amino Acids } \\
\hline Alanine & - & + & - & - & {$[75][45]$} \\
\hline Tryptophan & - & + & - & - & {$[102][4]$} \\
\hline Threonine & - & + & - & - & {$[102][4]$} \\
\hline Cysteine & - & + & - & - & {$[102]$} \\
\hline Isolucine & - & + & - & - & {$[102][4]$} \\
\hline Lucine & - & + & - & - & {$[102][4]$} \\
\hline Phenyl alanine & - & + & - & - & {$[102][4]$} \\
\hline Arginine & - & + & - & - & {$[4]$} \\
\hline Glutamic acid & - & + & - & - & {$[102][4]$} \\
\hline Serine & - & + & - & - & {$[102][4]$} \\
\hline Tyrosine & - & + & - & - & {$[102][4]$} \\
\hline Valine & - & + & - & - & {$[102][4]$} \\
\hline Histidine & - & + & - & - & {$[102][4]$} \\
\hline
\end{tabular}

Continued.... 


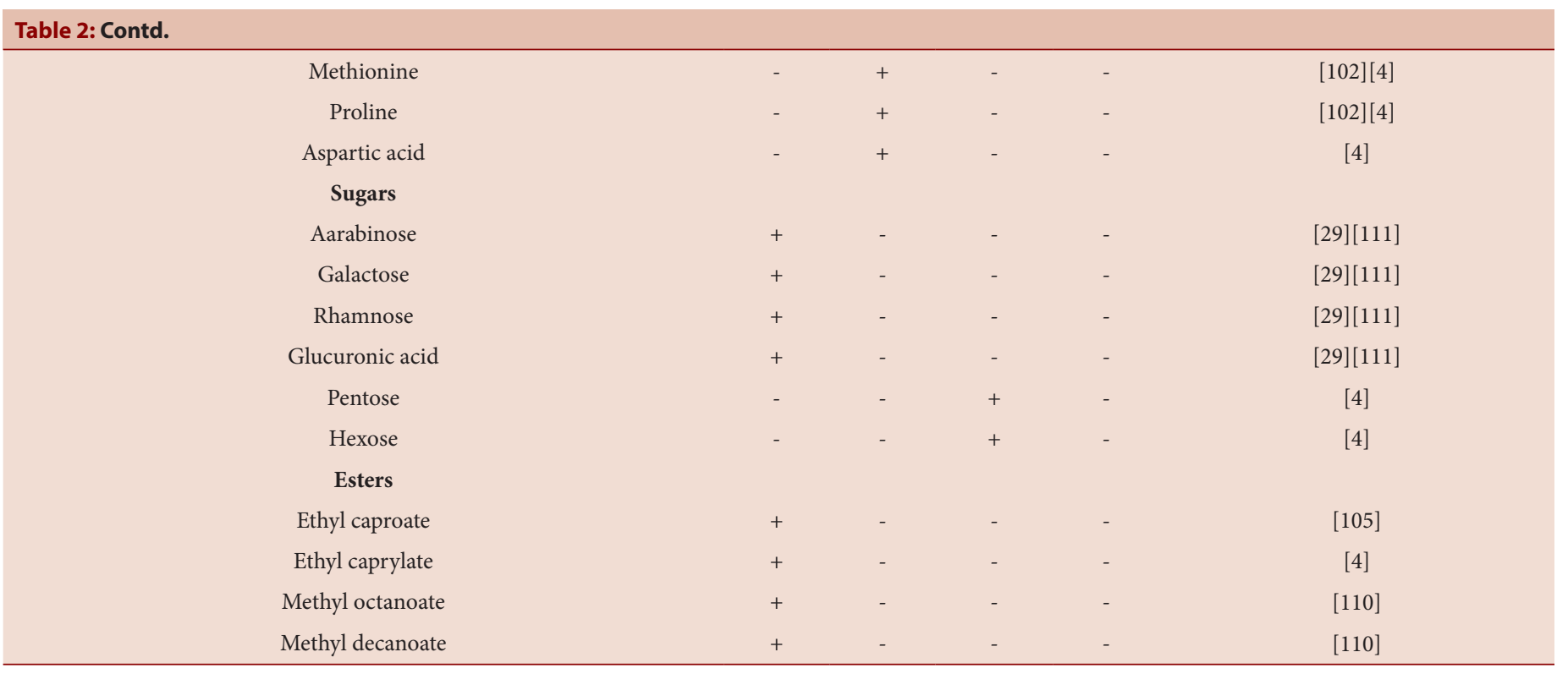

* Part of the plant is not reported

+ Present, - Absent.

Table 3: Volatile components present in Noni juice ${ }^{19}$

\begin{tabular}{|c|c|}
\hline \multicolumn{2}{|r|}{ Volatile components } \\
\hline Aldehydes and ketones & $\begin{array}{l}\text { Acetaldehyde, 2-methylebutanol, 3-methylebutanal, 2-pentanone, 3-methyle-2-butanone, 2-hexanone, 2-Hexenal, Furfural, } \\
\text { Benzaldehyde }\end{array}$ \\
\hline Acids & Formic acid, Acetic acid, Butanoic acid, Hexanoic acid, Heptanoic acid, Octanoic acid, 2-octanoic acid, Nonaoic acid, Decanoic acid \\
\hline Alcohols & Ethanol, 2-methyle-3-buten-1-ol, 1-butanol, 3-Methyl-3-buten-1-ol, 3-Methyl-2-buten-1-ol, Benzyl alcohol \\
\hline Esters & $\begin{array}{l}\text { Ethyl acetate, Butyl acetate, Methyl 2-methylepropanoate, Methyl butanoate, Ethyl butanoate, Butyl butanoate, Methyl } \\
\text { 3-methylbutanoate, 4-Pentenyl butanoate, 3-Methyl-3-buten-1-yl 3-methylbutanoate, Methyl 2-methylbutanoate, Methyl hexanoate, } \\
\text { Methyl 2-methylbutanoate, Methylehexanoate, Ethyl hexanoate, Butyl hexanoate, 4-pentanyl hexanoate, 3-Methyl-3-buten-1- } \\
\text { yl hexanoate, Hexyl isovalerate, Methyl heptanoate, Methyl octanoate, Ethyl octanoate, Butyl octanoate, 3-Methyl-3-buten-1-yl } \\
\text { octanoate, Methyl 2-octenoate, Methyl 3-octenoate, Methyl 3-octenoate, Methyl nonanate, Methyl 5-nonanate, Methyl decanoate, } \\
\text { Ethyl decanoate, Methyl 4-decanoate, Ethyl 4-decanoate, Methyl salicylate, Methyl hexadecanoate }\end{array}$ \\
\hline Terpenes & Linalool oxide, (Z)-3,7-Dimethyl-1,3,6-octatriene, (+)-4-Carene, D-Limonene, Ocimenol, Terpineol \\
\hline Sulfur Compounds & $\begin{array}{c}\text { Methanethiol, S-Methyl thioacetate, Dimethyl disulfide, Methyl 3-methylthiopropanoate, Ethyl 3-methylthiopropanoate, } \\
\text { 3-methylthiopropanoic acid }\end{array}$ \\
\hline
\end{tabular}

\section{Phytoconstituents present in various parts of Noni plant represented with structure (Figure 5, 6, 7, 8, 9, 10)}

Researchers isolated ninety six volatile components from Noni fruit at two different ripening stages (ripe and over ripe). Over ripened fruit showed significantly higher amounts of methyl hexanoate, methyl octanoate, ethyl octanoate and methyl 4 E-decenoate, while octanoic acid and decanoic acid concentrations were significantly low. These changes indicates that esterification occurs during maturation. Two unsaturated esters, 3-methyl-3-buten-1-yl hexanoate and 3-methyl3-buten-1-yl octanoate significantly decreased in their concentrations in the ripe to over-ripe fruits. ${ }^{17}$ Noni blossoms are found to contain iridoids and flavonoids as major phytochemicals. ${ }^{18}$ It has also been reported that the volatile components viz. aldehydes, ketones, esters, alcohols, terpenes and sulphur compounds (Table 3 ) are present in ripe Noni fruit. This suggested that the presence of sulphur contributes to the flavour characteristics of Noni juice. ${ }^{19}$ It was suggested that the production process (fermentation and juice vs drying or lyophilization) has no effect on the anthraquinone content. In ripe fruit there is no as such influence on anthraquinone content. Also, suggested that commercial Noni products in the market whether fermented or unfermented juice or powder should be obtained from fully ripe Noni fruits and seed should be removed during drying process. ${ }^{20}$

Compared the Total Phenolic Content (TPC) of commercial Noni juice with blueberry and grape juice, reported that Noni juice contains $65.56 \%$ of total polyphenols against $27.90 \%$ and $6.54 \%$ which represent the $5 \%$ blueberry and grape juice, respectively. Blue berry and grape juice mask the unpleasant odour and bitter taste of Noni fruit juice and allows alteration in the organoleptic properties of commercialized Noni juice. Commercial Noni juice presented higher values of TPC $(91.90 \mathrm{mg}$ of gallic acid/100 $\mathrm{ml}$ juice) and antioxidant activity (5.85 mmol/L) when compared to its $5 \%$ diluted constituents. ${ }^{21}$

Identified polyphenols belonging to the coumarin, flavonoid and phenolic acid groups, and two iridoids in Noni juice by HPLC-DAD and Electro Spray Ionization Mass Spectrometric detection (HPLC-ESI-MS) method. Noni juice have free radical scavenging capacity. Furthermore, it also reduced carrageenan induced paw edema, directly inhibited COX-1 
and COX-2 activities and inhibited the production of nitric oxide (NO) and prostaglandins $\mathrm{E}(2)$ in activated $\mathrm{J774}$ cells, in a dose dependent manner. ${ }^{22}$

\section{Mechanism of action of phytoconstituents present in various parts of Noni plant}

\section{Damnacanthal}

Damnacanthal, an anthraquinone induced normal morphology and cytoskletal structure in K-ras NRK cells at the tolerant temperature without changing the amount and localization of ras. The effect of damnacanthal was reversible and had not shown any effect on the morphology of RSVTs-NRK cells states the src oncogene. Hence, damnacanthal is a new inhibitor of ras function. ${ }^{23}$ The MTT method confirmed that damnacanthal inhibitor the growth of MCF-7 cells at the concentration of 8.2 $\mu \mathrm{g} / \mathrm{ml}$ for $72 \mathrm{~h}$. Moreover, damnacanthal was found to induce cell cycle (CC) arrest at the G1 check point in MCF-7 cells by CC analysis. The result provided significant evidence in demonstrating that p53-mediated damnacanthal induced apoptosis through the activation of p21 and caspase- $7 .^{24}$

In another study, it was reported that damnacanthal acts against Hep G2 hepatocellular carcinoma cells by decreasing the phosphorylation level of Akt and targets matrix metalloproteinase-2 secretion in Hep G2 cells. ${ }^{25}$ Reported that the damnacanthal possesses strong inhibitory activity towards tyrosine kinases i.e. Lck, Src, Lyn and EGF receptor. ${ }^{26}$

\section{Epigallocatechin gallate (EGCG)}

EGCG present in Noni which is known for its potent antioxidant and antiangeogenesis activity also it inhibits the quinol oxidase (NOX) enzyme, which is responsible for tumor activity. Thus, Noni helps in antiangiogenesis by inhibiting NOX. ${ }^{27}$

\section{Alizarin and limonene}

Found to inhibit the formation of blood vessels over the tumor by antiangeogenesis property. Thus Noni juice inhibit the growth and mutations of malignant cells and induce programmed cell death or apoptosis. ${ }^{28}$

\section{Polysaccharides}

Glucoronic acid, galactose, arabinose, rhamnose, glycosides and trisaccharide fatty acid ester showed immuno-stimulatory, immune-modulatory, antibacterial, antitumor and anticancer activity. ${ }^{29} 6-\mathrm{D}$-Glucopyranose pentaacetate is sulphated polysaccharides, which undermine the interaction between glucosaminoglycan and certain proteins. This helps to block the ability of mutated cells to adhere to new cells stopping metastasis. ${ }^{30}$

Compounds present in Noni fruit like iridoid glycosides, 6-alpha hydroxyadoxoside, 6 beta, 7-beta-epoxy-8-episplenoside as well as americanin, narcissoside, asperuloside, asperulosidic acid, citrifolin Bepimera, borreriagenin, deacetylasperuloside, dehydromethoxy gaertneroside, cytidine, epi-dihydrocornin, d-glucose, d-mannitol, methyl alpha-dfructofuranoside, methyl beta-d-fructofuranoside, nicotifloroside, and beta-sitosterol 3-O-beta-d-glucopyranoside showed antioxidant activity in both $\mathrm{DPPH}$ and $\mathrm{NO}_{2}$ reducing activity bioassays. ${ }^{31}$ Researcher's states that Noni has good antioxidant activity, having free radical scavenging activity and quenching lipid peroxides. ${ }^{32}$

\section{Quercetin}

Reported decreased cell viability of both low metastatic cell line ACC-2 and high metastatic cell line ACC-M with quercetin treatment in a concentration and time dependent manner. Quercetin significantly decreases the apoptosis in ACC cells through a mitochondria dependent pathway which showed close correlation with down regulation of the PI3K/Akt/IKK-alpha/NF-kappaB pathway. Their result reveals that quercetin may be a hopeful chemotherapeutic agent against ACC through its function of down regulating the PI3K/Akt/IKK-alpha/NFkappaB signaling pathway. ${ }^{33}$

\section{Scopoletin}

Scopoletin decreases carrageen induced iNOS and COX-2 expressions in the paw edema. These anti-inflammatory mechanisms of scopoletin may be related to the reduced in the level of MDA via increasing the activities of SOD, GPx and CAT in the paw edema. ${ }^{34}$

Xeronine

Noni fruit contain proxeronine which combine with proxeroninase an enzyme present in the body to form xeronine which may help to enlarge the pore size of the tumor cells and allow anticancer drugs to enter the cells more easily. Also, xeronine increases the permeability of $\mathrm{K}^{+}$ions and prevent the formation of lactic acid from glucose. ${ }^{12}$

\section{Citrifolinoside}

Citrifolinoside isolated from the leaves of $M$. citrifolia plant showed significant inhibition of UVB-induced Activator Protein-1 (AP-1) activity in cell cultures. ${ }^{35}$

\section{Monoterpene}

A monoterpene, limonene present in Noni fruit has been shown to prevent mammary, liver, lung and other cancers. Limonene stimulate thymus gland to secrete more T cells which destroy the carcinoma cells. ${ }^{36}$

\section{Beta carotene}

Suggested that beta carotene reduced the oxygen free radical and prevent oxidative damage. Also reported that long term use of moderate dose of $\beta$-carotene significantly reduced prostate cancer incidence in male smokers. $^{37}$

\section{Ursolic acid}

It possess anti-carcinogenic effect both externally and internally prevent growth of cancerous cells and induce apoptosis by modulating immune process of the body. ${ }^{38}$

\section{Gallic acid}

Gallic acid reduced compound 48/80-or immunoglobulin E (IgE) which induced histamine release from mast cells. The inhibitory effect of gallic acid on the histamine release was mediated by the modulation of cAMP and intracellular calcium. Gallic acid decreased the phorbol 12-myristate 13-acetate and calcium ionophore A23187-stimulated pro-inflammatory cytokine gene expression and production such as TNF-a and IL-6 in human mast cells. ${ }^{39}$

\section{Preparation and standardization of Noni formulations}

Reported there are two types of Noni juice on the basis of extraction like traditional and non-traditional; and other different formulations like Noni beverage, Noni squash, Noni syrup (Figure 11, 12, 13, 14, 15) analysed for $\mathrm{pH}$, total soluble solids, acidity, reducing sugar, total phenol, ascorbic acid, tannins and pectin by standard methods. ${ }^{40}$ The colour of Noni juice is measured by using Lovi bond tintometer ${ }^{41}$ As per the method of standardization reported, Quantity of sugar, citric acid, water, ginger extract including organoleptic characters can be used for the standardization of Noni juice.

Standardized Noni beverages like Ready to Services (RTS), Squash and Syrup which are prepared from Noni fruit juice. RTS was reported to contain $130 \mathrm{~g}$ sugar, $100 \mathrm{ml}$ Noni fruit juice and $20 \mathrm{ml}$ ginger extract in $770 \mathrm{ml}$ water. Squash was found to add with $1500 \mathrm{~g}$ sugar, $7 \mathrm{~g}$ citric acid and $250 \mathrm{ml}$ Noni fruit juice in $486 \mathrm{ml}$ water. Noni syrup was found to be prepared by adding $680 \mathrm{~g}$ sugar, $10 \mathrm{~g}$ citric acid and $250 \mathrm{ml}$ Noni juice in $310 \mathrm{ml}$ of water. ${ }^{42}$ 


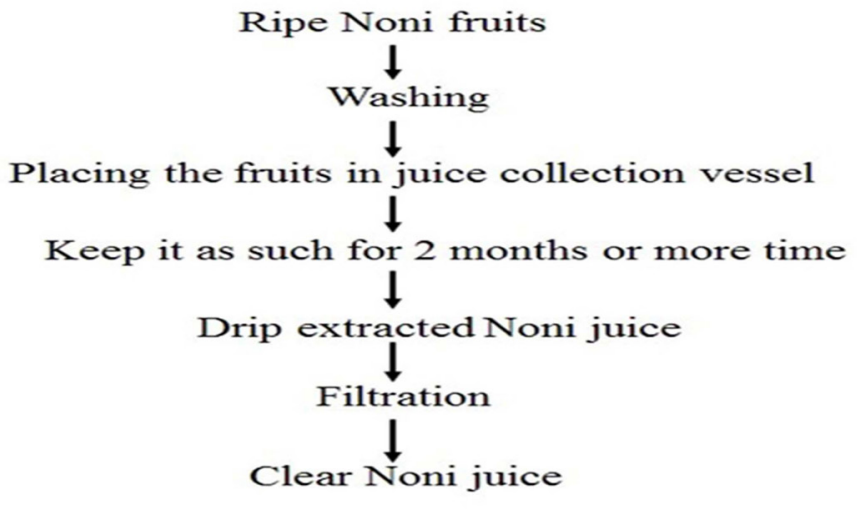

Figure 11: Flow sheet for production of traditional Noni juice.

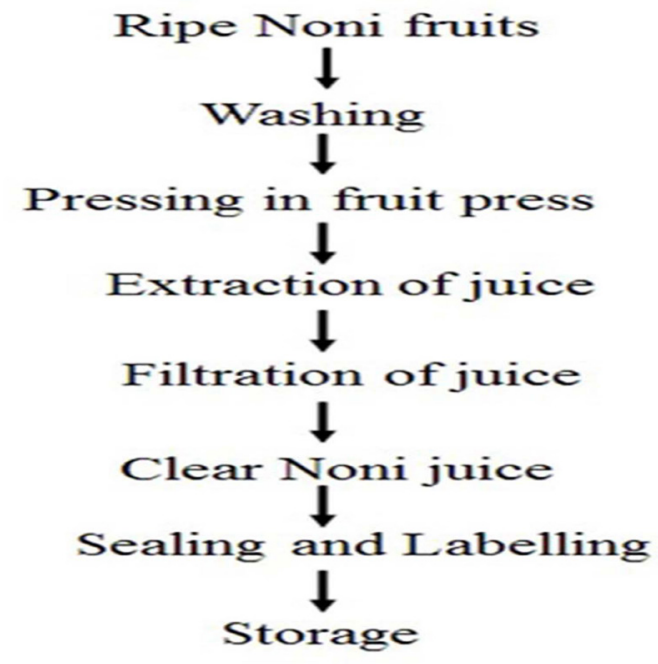

Figure 12: Flow sheet for production of Non-traditional Noni juice.

Fruit juice/Extract

(Fermented drip extract)

Addition of sugar of (13\%), water Make acidity as per sufficient quantity

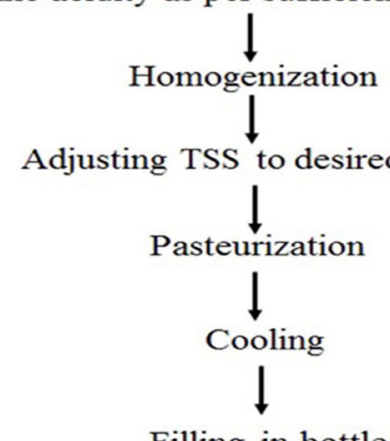

Filling in bottle

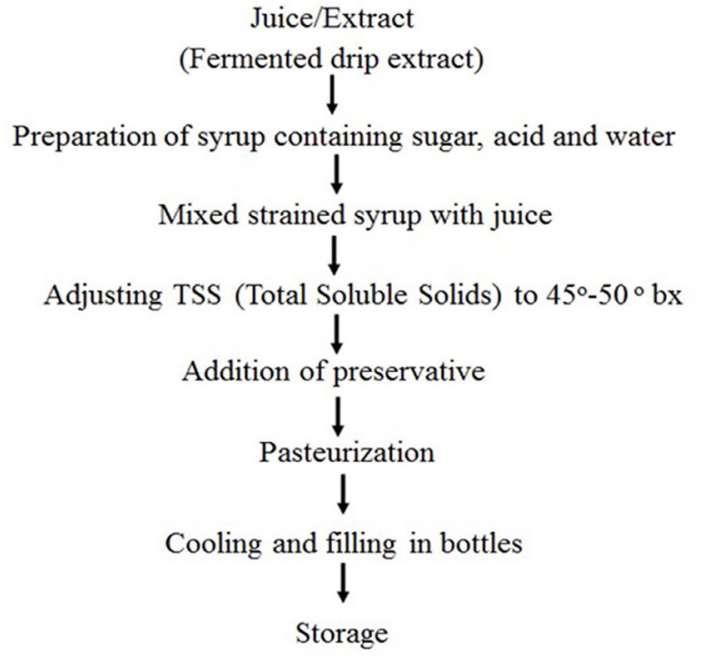

Figure 14: Preparation of Noni squash.

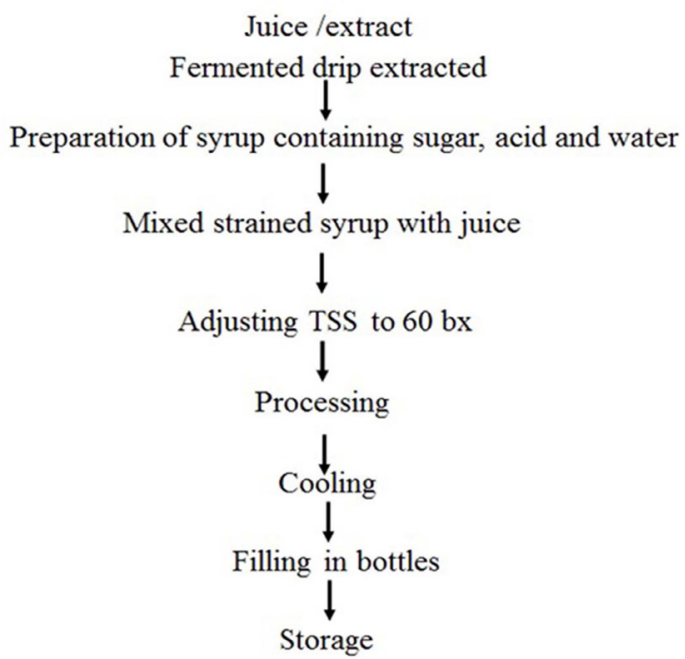

Figure 15: Preparation of Noni syrup.

\section{Proximate chemical composition of Noni fruit}

The acidity of Noni juice extracted was reported to be $1.6 \%$. The protein, ash and moisture content in Noni fruit reported as per (http://www. healingnoni.com) was $0.24 \%, 0.54 \%$ and $95.67 \%$ but the protein, ash and moisture content was $0.43 \%, 0.43 \%$ and $89.6 \%$ respectively also they carried out a study to improve the taste and flavour of the Noni fruits quash preparation. They diluted Noni juice with water at the ratio of 1:0.5, 1:1, 1:2 and 1:3 concentrations and converted into RTS containing $220 \mathrm{bx}, 160 \mathrm{bx}, 140 \mathrm{bx}$ and $100 \mathrm{bx}$ T.S.S., and evaluated for overall quality. It was found that the squash diluted in 1:3 proportion tasted better and having good flavour with consumer acceptance. Same authors carried out a study to improve the taste and flavour of the Noni syrup preparation. They diluted juice with water at the ration of 1:1, 1:2, 1:3 and 1:4 concentrations. It was found that the juice diluted with water in the ratio of 1:4 tasted better as compared to other concentrations. Finally they concluded that the squash and syrup with 1:3 and 1:4 dilutions respectively are more acceptable. ${ }^{42}$ 
Identified, developed and validated various constituents present in Noni juice by HPLC-MS method and quantitative data on the composition of Noni juice, including iridoid glucosides, scopoletin, rutin, fatty acid, sugar, and anthraquinones are reported. ${ }^{43}$ Four characteristic analytes like scopoletin, rutin, quercetin, and 5, 15-DMM were detected in Noni fruits and commercial juices originating from different regions of the world, but in a significantly various ranges of concentration. Together, these characteristic components can be used as a reference for identification and authentication of Noni fruit raw materials and commercial Noni products. ${ }^{44}$

\section{Challenge in standardization of Noni preparations}

The variation in phytochemical content in Noni fruits and juices may suggest different toxicological and pharmacological properties. While there are over 300 peer-reviewed scientific publications on Noni, data regarding efficacy and safety of one commercial Noni product may not be applicable to any others. So there is an urgent need for establishment of method of standardization of Noni preparations which is accepted worldwide and can be applicable to all Noni preparations.

\section{Pharmacological Activity of Noni}

\section{Preclinical investigations}

\section{Effect on lung and colon cancer}

In a recent study reported six known chemical compounds and two new compounds isolated from roots of the plant showed significant inhibitory effects on the proliferation of human lung and colon cancer cells. ${ }^{45}$

\section{Effect on esophageal cancer}

Reported in an in-vivo and in-vitro studies that black or red raspberries, strawberries, blueberries, Noni, wolfberry, inhibits the development of cancer by signifying that the all possesses both preventative and curative effects on rat esophageal cancer induced by $\mathrm{N}$-nitrosomethylbenzylamine. ${ }^{46}$

\section{Effect on breast cancer}

The effects of Tahitian Noni Juice (TNJ) were tested on mammary carcinogenesis in MMTV-neutransgenic mice. Reported TNJ treatment did not affect mammary tumor latency, multiplicity and metastatic incidence. But TNJ showed significant diminution in tumor weight, size and longer tumor repetition times in mice. Overall, it was observed that, a mouse equivalent of dose for humans $(<3 \mathrm{oz} /$ day) remarkably inhibited the growth of mammary gland cancer. ${ }^{47}$

Investigated the effect of Noni juice on Ehrlich ascites tumors bearing Balb-c mice, concluded that Noni juice may be useful in the treatment of breast cancer either on its own or in combination with doxorubicin. This is because of the effect of Noni juice on Ehrlich ascites tumors bearing Balb-c mice, which produced significantly smaller, short and long diameters of the tumor tissues in each treated group compared to those in control group either alone or with doxorubicin. ${ }^{48}$

Reported the anti-growth effect of TNJ in one hundred and sixty female Sprague-Dawley rats. TNJ was found successful in reducing number of palpable tumors per group significantly in all the groups in which $3 \%$, $5 \%$, and $10 \%$ TNJ was administered. TNJ also found to significantly reduce the multiplicity and malignancy of lesions, and the survival rate of animals when compared with positive controls at different time points. ${ }^{49}$

\section{Effect on colorectal cancer}

Damnacanthal is able to suppress cancer in colorectal tumor genesis by the findings that damnacanthal exhibited cell growth arrest as well as caspase activity induction. Result suggests that damnacanthal having potent antitumorogenic activity in human colorectal cancer cells. ${ }^{50}$

\section{Effect on cervical cancer}

Noni juice and cisplatin, either alone or in combination was able to induce apoptosis through the mitochondrial pathway on $\mathrm{HeLa}$ and $\mathrm{SiHa}$ cells. However, cisplatin showed slightly higher cell killing when compared to Noni juice while their combination showed additive effects. This result suggests that Noni juice can be used as a chemo adjuvant in the treatment of cervical cancer. ${ }^{51}$

\section{Antitumor activity}

Noni juice has been found to improve survival time and produce curative effects when Noni-ppt (Noni-ppt obtained from Noni juice) was combined with sub-optimal doses of the standard chemotherapeutic agents like cisplatin, doxorubicin, 5-fluorouracil and vincristine. Their result suggests that Noni-pptis a good supplemental agent in cancer treatment. ${ }^{29}$ Reports of $10 \%$ concentration of Noni juice in growth media induce vessel degeneration and apoptosis within a few days. They also found that $10 \%$ Noni juice in media was an effective inhibitor of capillary initiation in explants from human breast tumors. ${ }^{28}$

\section{Chemoprotective effect}

Evaluate the chemoprotective effect of ethanolic extract of $M$. citrifolia (EEMC) fruits by simultaneous administration orally at the dose of 100 and $200 \mathrm{mg} / \mathrm{kg}$ b.wt. in rats. Cisplatin $5.0 \mathrm{mg} / \mathrm{kg}$ was administered through i.p. route to induce nephrotoxicity. They determined serum biochemical parameters like serum creatinine, protein and urea as indicators of kidney damage. In result both doses has shown significant nephroprotective activity, which was confirmed by histopathological study. ${ }^{52}$

\section{Effect on cardiovascular system}

Noni fruit has the ability to prevent arteriosclerosisis related to the oxidation of low density lipoproteins (LDLs). They state that this beneficial effect could be due to presence of lignans..$^{53}$

\section{Anti-psychotic activity}

Acute treatment of $M$. citrifolia (1, 3, 5, $10 \mathrm{~g} / \mathrm{kg}$, p.o) significantly decreased apomorphine induced cage climbing behavior and climbing time in mice in a dose dependent manner. Similar significant inhibition of methamphetamine-induced stereotypy behavior and climbing time in mice was observed dose dependently. The 7 and 21 days treatment of TNJ in drinking water at 50 and $100 \% \mathrm{v} / \mathrm{v}$ significantly improved the apomorphine induced climbing behavior and climbing time in mice. These results suggest that TNJ has potential effect in the treatment of psychiatric disorders. ${ }^{54}$

\section{Anti-depressant activity}

A number of scientists have investigated the potential action of some plants i.e. Hypericum perforatum, Ginkgo biloba, Apocynum venetum, Valeriana officinalis, Melissa officinalis and M. citrifolia for the treatment of depression and anxiety. ${ }^{55}$ Additionally recent studies showed $M$. citrifolia as an inhibitor of MAO-A and MAO-B. ${ }^{56}$

\section{Effect on cognitive function}

Another study investigated the effects of fruit juice on stress-induced impairment of cognitive function in mice using Morris water maze. They suggested that Noni juice protect brain from stress-induced impairment of cognitive function and reported this protective effect may be related to improvement in stress-induced decrease in blood vessel density in the hippocampal dentate gyrus. ${ }^{57}$

\section{Effect on nervous system}

Researchers evaluated the protective effect of Noni juice on brain damage caused by ischemic stress in mice focused on the effect of fruit juice on the development of the post-ischemic glucose intolerance as a cerebral 
protective mechanism. This mechanism may provide the neuronal protective effect of Oral Noni Juice (ONJ) against ischemic stress as derived from the above results..$^{58}$

\section{Effect on Alzheimer's disease}

Evaluation of neuroprotective effect of Noni juice against scopolamine induced memory loss in mice indicated that oral administration of Noni juice developed reversible impairment of retention in step down latency inhibitory test. From the above result, authors assumed that Noni juice offers a protective effect against oxidative damage induced by scopolamine by maintaining the activities of superoxide dismutase (SOD) and concluded that Noni juice might be a potential therapeutic alternative in either the prevention or the treatment of alzheimer's disease. ${ }^{59}$

\section{Wound healing activity}

M. citrifolia leaf extract was found to possess wound healing activity. Observations showed decrease in lipid peroxide level in $M$. citrifolia treated group which may be because of the presence of $\beta$-carotene, flavonol and iridoid glycosides that are antioxidant in nature is reported. ${ }^{60}$

\section{Immunostimulant activity}

Immune enhancing properties of $M$. citrifolia fruit enable the plant to exhibit immunostimulant activity on T and B lymphocytes as reported. ${ }^{61}$

\section{Hepatoprotective activity}

Acute liver injury induced by carbon tetrachloride $\left(\mathrm{CCl}_{4}\right)$ in female Sprague-Dawley (SD) rats was found reversed by Noni juice. In the placebo group, administered $\mathrm{CCl}_{4}$ with drinking water which was induced liver damage in rats. While in control group, pretreatment with $20 \%$ Noni juice in drinking water $+\mathrm{CCl}_{4}$ markedly decreased hepatotoxic lesions. Concluded Noni juice have liver protective effect from extrinsic toxin exposure. ${ }^{62}$

\section{Antioxidant activity}

Evaluated the beneficial effects of Noni juice on antioxidant, haematological and biochemical changes caused by N-Methyl-N-Nitrosourea (NMU) induced mammary carcinogenesis in Sprague-Dawley rats. Results showed that Noni juice treatment significantly increased antioxidant enzymes level such as catalase, SOD and significantly decreased lipid peroxidation level in NMU challenged group when compared to NMU control group. Noni juice also showed a preventive effect against anemia, lymphocytosis and neutrophilia when compared to NMU control group. They concluded that Noni juice have liver and kidney protective effect in NMU induce carcinogenesis and could be useful to treat mammary gland in humans and animals. ${ }^{63}$

The antioxidant properties of ethanol and ethyl acetate extracts of root, fruit and leaf of $M$. citrifolia assessed by ferric thiocyanate method (FTC) and thiobarbituric acid methods (TBA) which indicated that the root extract showed higher activity than the fruit or leaf extracts. ${ }^{64}$

\section{Anti-inflammatory activity}

Bradykinin induced inflammatory response was inhibited and rapid collapse in rat paw edema were pretreated either by oral or i.p administration with Noni juice extract. This effect may be a result of interference with the B2 receptor mediated mechanism by which bradykinin induces rat paw edema. ${ }^{65}$ Another study concludes that $M$. citrifolia juice selectively inhibits cyclo-oxygenase enzymes (COX-1 and COX-2) involved in breast, colon and lung cancer and shows anti-inflammatory activity. ${ }^{66}$

\section{Antidyslipidemic activity}

In an evaluation of antidyslipidemic effect of aqueous ethanolic extracts of different parts of $M$. citrifolia viz. fruits, leaves and roots, concludes the mechanism of antidyslipidemic effects of fruits, roots and leaves of
M. citrifolia through various pathways i.e. inhibition of biosynthesis, absorption and secretion of lipids. The results indicate that Noni can be used as a potential medicine for cardiovascular diseases. ${ }^{67}$

\section{Antilipidemic activity}

The effect of Noni seed oil on serum lipid levels in normal lipidemic and hyper lipidemic mice were evaluated and found a reduction in total cholesterol and triglyceride levels in both models are reported. ${ }^{68}$

\section{Effect on GIT}

Noni juice inhibits gastric emptying by stimulation of cholecystokinin (CCK) secretion which occurs simultaneously with an increase in plasma CCK cholecystokinin 1 (CCK1) receptors that are involved in the Noni induced inhibition of gastric emptying. ${ }^{69}$ Scopoletin is a phytoconstituent present in Noni fruit found to be effective as a potential preventive and therapeutic agent for gastro-esophageal inflammatory diseases through its anti-secretory and prokinetic activities including an inhibitory activity on serotonin, free radicals, and cytokine-mediated inflammation. ${ }^{70}$

\section{Antimicrobial activity}

Powder form of various extracts of Noni leaves increases the growth inhibition activity of E. coli, Staphylococcus aureus, Candida albicans and Aspergillus niger in a dose dependent order. The overall result indicates the use of solvent extracts of Noni leaves is effective in the treatment of infectious disease. ${ }^{71}$

\section{Antifungal activity}

Methanolic extract of the dried Noni fruit exhibited maximum percentage of inhibition against Trichophyton mentagrophytes (79.3\%), while approximately 50\% activity was recorded against Penicillium, Fusarium and Rhizopus species. ${ }^{72}$

\section{Antiviral activity}

1-methoxy- 2-Formyl-3-hydroxyanthraquinone isolated from Noni roots suppressed the cytopathic effect of HIV infected MT- 4 cells, without inhibiting cell growth and removal of endothelium. ${ }^{73}$

\section{Hypoglycemic activity}

Fermented Noni juice used to investigate the hypoglycemic activity in diabetes-induced rats. On the $20^{\text {th }}$ day, after treatment in diabetic experimental animals, showed significant decrease in fasting glucose from an excess of $300 \mathrm{mg} / \mathrm{dl}$ (day 3) to $150 \mathrm{mg} / \mathrm{dl}$ (day 20). It can be assumed that $M$. citrifolia either potentiates the action of insulin directly or that it increases peripheral tissue sensitivity to the storage hormone. ${ }^{74}$

\section{Smooth muscle stimulatory activity}

Reported that the dried fruit has smooth muscle stimulatory activity and histaminergic effects based on tests conducted for biological activities in animal and anti-microbial studies. ${ }^{75}$

\section{Spasmolytic activity}

Noni plant root extract possess antispasmodic, vasodilator and cardio depressant activities which are mediated through blockade of calcium channel as well as release of calcium from intracellular calcium which may make clearthe use of $M$. citrifolia in diarrhea and hypertension. ${ }^{76}$

\section{Anti-osteoporotic activity}

Isolated seven anthraquinones from an ethanolic extract of the roots of M. citrifolia. Reported all the isolated components were found to inhibit osteoclast tartrate resistant acid phosphatase (TRAP) activity and bone resorption including the inhibitory effects on osteoclastic bone resorption in osteoporotic rats. Finally they suggested all the components have positive therapeutic effect against osteoporosis. ${ }^{77}$ 


\section{Immunomodulatory effect}

In in-vitro study, TNJ and fruit juice concentrate potently activated the cannabinoid $2\left(\mathrm{CB}_{2}\right)$, but inhibit the cannabinoid $1\left(\mathrm{CB}_{1}\right)$ receptors in a concentration-dependent manner. But in-vivo studies reported decreased the production of IL- 4 and increased the production of IFN- $\gamma$. These results suggested that Noni juice modulates the immune system via activating of the $\mathrm{CB}_{2}$ receptors and suppressing of the IL- 4 but increasing the production of IFN- $\gamma$ cytokines. ${ }^{78}$

\section{Nephroprotective activity}

Fruit juice can modify renal function and catecholamine contents in doxorubicin induced nephrosis, it was reported that Noni juice reduced plasma cholesterol; doxorubicin induced impaired renal function in rats along with compensatory increase in renal dopamine content. But no beneficial effects on renal function were observed when fruit juice was administered with doxorubicin. ${ }^{79}$

\section{Bone protective effect}

Investigation on roots of Morinda officinalis reports its protective effect against bone loss in sciatic neurectomized and ovariectomized osteoporotic rats, which is due to the present of anthraquinone (1,3,8-trihydroxy-2-methoxy-anthraquinone 2-hydroxy-1-methoxyanthraquinone and rubiadin) in the plant. ${ }^{80}$

\section{Clinical investigations}

\section{Safety study}

Some researchers conducted safety study of Noni fruit juice on ninety six healthy volunteers where different quantities of fruit juice were administered daily in the order $0 \mathrm{ml}$ (placebo), $30 \mathrm{ml}, 300 \mathrm{ml}$, or $750 \mathrm{ml}$. It was found that $300 \mathrm{ml}$ significantly reduced the adverse events like headache, cough, nausea, menstrual cramp, nasal discharge and vomiting, upper respiratory and urinary tract infections. ${ }^{81}$

\section{Anticancer activity}

Consume 1 to $4 \mathrm{oz}(1 \mathrm{oz}=30 \mathrm{ml})$ of $\mathrm{TNJ}$ daily may reduce the cancer risk in heavy cigarette smokers by blocking carcinogen DNA binding is suggested. ${ }^{82}$ In another one month clinical trial on 68 current smokers, supplemented with two ounces of TNJ $(n=38)$ or placebo $(n=30)$ twice a day for 30 days which resulted in protection from oxidative damage induced by cigarette smoke and thereby reduced cancer risk related to smoking. ${ }^{83}$

\section{Antioxidant activity in heavy smokers}

Evaluated the antioxidant activity of TNJ in double-blind and placebo controlled clinical trial with 285 current heavy smokers for 30 days. Reported TNJ lowered free radicals viz. superoxide anion radicals (SAR) and lipid hydroperoxide (LOOH) levels significantly and observed no significant reductions in SAR or LOOH levels in the placebo group. ${ }^{84}$

\section{Noni protect Malondialdehyde (MDA)-DNA adducts in heavy smokers}

In one month clinical trial on 203 people, placebo-controlled trial, found TNJ reduced the amount of MDA caused DNA damage by $53 \%$, and concluded TNJ is able to reduce the MDA-DNA adduct level at a tremendously significant level. The result suggests that it may reduce cancer risk in current smokers. ${ }^{85}$

\section{Effect on cholesterol and triglyceride level in heavy smokers}

Conducted one month clinical trial double-blind and placebo controlled in 132 heavy smokers with cholesterol level more than $190 \mathrm{mg} / \mathrm{dl}$. Authors are reported TNJ decreases total cholesterol and triglyceride levels in current smokers. So they concluded that drinking TNJ may prevent heart disease. ${ }^{86}$

\section{Case studies}

Reported on two case studies of gastric cancer patients being treated with Noni juice. Case 1: Doctor advice a male patient aged 69 years, to do surgery otherwise he would die within few months. But the patient ignored doctor's advice and he became in capacitated within two months as his body weight dropped from 165 to 79 pounds. He started to take homemade Noni juice and he is improved within a month and continued 6 months after that he stopped Noni juice. Seven years he has not got any gastric problem but in biopsy examination showed histology similar to his original cancer not increased so the patient again started Noni juice after that outcome was not reported. Case 2: A patient was 64 years old with gastric cancer, examined in gastrectomy, reported the cancer had spread to 17-28 lymph nodes and he was given 5 years to live. After that started to consume homemade Noni juice and he lived 16 years more, he died at age 80 of malnutrition due to gastric cancer. ${ }^{87}$

\section{Effect in hypertension}

One month open label clinical trial on 10 people by daily administrating of $4 \mathrm{oz}$. of TNJ, Reported Noni juice significantly decreased the high blood pressure, especially systolic high blood pressure. ${ }^{88}$

\section{Effect on cholesterol in non-smokers}

One month pilot study on 10 non-smoking hypercholesteromic subjects, who are not currently taking cholesterol medications, consuming 4 ounces of TNJ daily for 30 days; lowered the average pre-test total cholesterol from 184.4 to 182.4 , at the end of the trial it increased the HDL/ LDL from 0.36 to 0.37 . Concluded that Noni juice has the potential to lower cholesterol through the mechanisms of inhibiting HMG-CoA reductase and hepatic/intestinal ACAT enzymes, acting as a dual inhibitor of both enzymes. ${ }^{89}$

\section{Effect of leaf extract in skin protection}

Noni leaf extract protected the skin against UV induced redness and swelling (erythema). Study suggests that leaves are safe for topical use and may be useful in mitigating UVB-induced injury to the skin. ${ }^{90}$

\section{Effect on skin care regimen}

Six week clinical trial of Noni based skin care regimen on 49 women, (age 38 to 55 years). Where in the subjects applied three formulations of Noni i.e. Noni juice, Noni seed oil and Noni leaf juice to the face and neck. Result shows significant reductions in lateral canthal fine lines and wrinkles and also stated that improved skin elasticity and firmness. There was no evidence of skin irritation was present in any participant at any time during the trial. Finally they concluded the trial results validate traditional uses of the Noni plant to improve skin health. ${ }^{91}$

\section{Effects on serum lipid profile}

A study reported that drinking 29.5 to $188 \mathrm{ml}$ of Noni juice per day reduces cholesterol, triglycerides, and hs-CRP. Also a decrease in LDL and homocysteine, as well as increase in HDL, among the Noni juice drinkers were observed. ${ }^{92}$

\section{Antidiabetic activity}

Lowering glucose levels under fasting and postprandial conditions are reported when type-2 diabetes patients habitually consumed Noni juice as a combination therapy (Noni and oral hypoglycemic agents). ${ }^{93}$

\section{Effect on osteoarthritis}

In three month open level intervention trial (82 osteoarthritis patients) administered $3 \mathrm{oz}$ of TNJ per day, reported significant improvements in symptoms such as pain and mobility. ${ }^{94}$ 


\section{Effect on menopause}

A three-month intervention pilot study by administering two ounces of TNJ. Reported TNJ possess anti-osteoporosis effect and also improved mood, energy and attenuated hearing loss. ${ }^{95}$

\section{Immune boosting \& antioxidant}

In two month pilot study TNJ found to increase adaptive immune system activity by $32 \%$ and innate immune system activity by $30 \%$ while decreasing oxidative stress in the body $19 \%{ }^{96}$

\section{Effect in endurance}

In a placebo-controlled, three week trial on 40 peoples, result revealed that TNJ increased the staying power by $21 \%$ and increased antioxidant activity by $25 \%$ when compared to placebo which showed no effect. Same researchers conducted drug screening test on six healthy adult volunteers ( 5 males and 1 female), consumed each volunteer $124 \mathrm{ml}$ of TNJ. Reported no unlawful drugs or their metabolites of TNJ are present in the urine samples collected from both male and female volunteers. ${ }^{97}$

\section{Effect on gingivitis/periodontitis}

Another study reports that the combination of good oral hygiene together with local and systemic treatment with Noni juice is a promising tool for the treatment of gingivitis and periodontitis. ${ }^{98}$

\section{Contraindication of Noni}

Noni juice is rich in potassium, hence it is not recommended for patients who have liver and kidney dysfunctions. The consumption of Noni juice produces hyperkalemia in patients with potassium restricted diets which could lead to nausea, muscle weakness and irregular heart beat. ${ }^{99}$ Another study reported the higher consumption of Noni juice during pregnancy delay ossification and skeleton alteration in the fetus. ${ }^{100}$

\section{CONCLUSION}

M. citrifolia is an herbal remedy commonly known as Noni. Traditionally various parts of Noni plant were used in Polynesian island as an herbal medicine in various ailments. Many scientific literatures suggests that it contains many chemical components viz. amino acids, anthraquinones, fatty acids, flavonoids, iridoids, lignans, polysaccharides, sterols etc. along with minerals, vitamins, micro and macro nutrients which are effective in many ailments. Researchers have proven in both preclinical and clinical models that Noni is pharmacologically active and can prevent cancer, heart disease, diabetes, cognitive dysfunction, hypertension etc., and maintain overall good health.

\section{ACKNOWLEDGEMENTS}

The authors are sincerely thankful to Noni Biotech Pvt. Ltd. Chennai. Authors are also thankful to Mr. Arun Chouthery, Plant Manager at Noni Biotech Pvt. Ltd. Chennai, for encouraging and providing the necessary guidelines, magazines, and scientific research materials of Noni to prepare this review.

\section{CONFLICT OF INTEREST}

The authors declare no conflict of interest. The authors themselves are responsible for the content and writing of the paper.

\section{ABBREVIATION USED}

TPC: Total Phenolic Content; NO: Nitric oxide CC: Cell cycle; EGCG: Epigallocatechingallate; NOX: Quinol oxidase, iNOS: Inducible nitric oxide synthase; MDA: Malondialdehyde; SOD: Superoxide dismutase; GPx: Glutathione peroxidase; CAT: Catalase, AP-1: Activator Protein-1; IgE: immunoglobulin E cAMP: Cyclic adenosine monophosphate; TNF- a: Tumor necrosis factor-a; IL-6: Interlukine-6, TSS: Total soluble solids, RTS: Ready to Services; bx: Brix; TNJ: Tahitian Noni Juice; EAC: Ehrlich ascites carcinoma; EEMC: Ethanolic extract of M. citrifolia; LDLs: Low density lipoproteins, MAO: Monoamine oxidase, ONJ: Oral Noni Juice, $\mathbf{C C l}_{4}$ : Carbon tetrachloride; SD: Sprague-Dawley; NMU: N-MethylN-Nitrosourea; FTC: Ferric thiocyanate, TBA: Thiobarbituric acid; CCK: Cholecystokinin, TRAP: Tartrate resistant acid phosphatase; $\mathbf{C B}_{2}$ : Cannabinoid 2; IFN- $\gamma$ : Interferon-gamma, oz: Ounce; DNA: Deoxyribonucleic acid; SAR: Superoxide anion radicals; LOOH: Lipid hydroperoxide; HDL/LDL: High-density lipoprotein/low-density lipoprotein; HMG-CoA: 3-hydroxy-3-methylglutaryl-coenzyme A; ACAT: AcetylCoenzyme A acetyltransferase; hs-CRP: High-sensitivity C-reactive protein.

\section{REFERENCES}

1. Potterat O, Hamburger M. Morinda citrifolia (Noni) fruit phytochemistry, pharmacology, safety. J Planta Med. 2007;73(3):191-99.

2. Honey J, Batra N, Bairwa R. Scientific basis of Noni Plant (Morinda citrifolia). Asian J Res Pharm Sci. 2012;2(2):45-7.

3. Anonymous. (20014b). Photogallery. Available at: http://luirig.altervista.org/photossearch/index.php?title=Morinda citrifolia, Accessed on 9 September 2014.

4. Dittmar A. (1993). L. Morinda citrifolia Use in indigenous Samoan medicine Journal of herbs Spices and Medicine Plants. 1993;1(3):77-92.

5. Shovic AC, Whistler WA. Food sources of provitamin A and vitamin $C$ in the American Pacific. Trop Sci. 2001;41(4):199-202.

6. Europian commission, Scientific Committee on Food. Opinion of the Scientific Committee on Food on new findings regarding the presence of acrylamide in food, health \& consumer protection directorate general. 2002.

7. Hirazumi A, Furusawa E, Chou SC, Hokama Y. "Immunomodulation contributes to the anticancer activity of Morinda citrifolia (Noni) fruit juice." Proc West Pharmacol Soc. 1996;39(2):7-9.

8. Morton JF. The ocean-going noni, or Indian mulberry (Morinda citrifolia, Rubiaceae) and some of its "colorful" relatives. Econ Bot. 1992;46(3)241-56.

9. Blanco YC, Fabrice V, Ana MP, Max R, Jean MB, Pierre B. The Noni fruit (Morinda citrifolia L.): A review of agricultural research, nutritional and therapeutic properties. Journal of Food Composition and Analysis, 2006;19(6):645-54.

10. Dixon AR, Heather M, Nina LK. (1999). Ferment this: the transformation of Noni, a traditional Polynesian medicine (Morinda citrifolia, Rubiaceae). Ecological Botony. 1999;53(1):51-68.

11. Nagalingam S, Changam SS, Kotturathu MC. Extraction and preliminary phytochemical screening of active compounds in Morinda citrifolia fruit. Asian Journal of Pharmaceutical and Clinical Research. 2012;52(2):179-81.

12. Heinicke RM. The Xeronine system: a new cellular mechanism that explains the health promoting action of Noni and Bromelain. Direct source publishing, Orem, Utah. 2001.

13. Samiraj R, Muthubalaji R, Rajeswari A, Ramaraj E, Subban P. Physicochemical, phytochemical and antimicrobial studies on Morinda citrifolia L. Fruits at different maturity stages. International Journal of Pharmacy and Pharmaceutical Sciences. 2012;4(5):473-76.

14. Mahanthesh MC, Manjappa AS, Shindhe MV, Jamkhandi CM, Jalapure SS Morinda citrifolia Linn; A medicinal plant with diverse phytochemicals and its medicinal relevance. World Journal of Pharmaceutical research. 2013;3(1): 215-32.

15. Samoylenko V, Jianping Z, Dunbar DC, Ikhlas AK, James WR, Ilias M. New Constituents from Noni (Morinda citrifolia) Fruit Juice. J Agric Food Chem. 2006;54(17):6398-402.

16. Long YX, Jiang MY, Hsieh KL, Liu JK. Chemical Constituents from the Seeds of Morinda citrifolia. Chin J Nat Med. 2009;7(2):119-22.

17. Pino JA, Eliosbel M, Clara EQ, Déborah C. Volatile compounds in noni (Morinda citrifolia L.) at two ripening stages. Ciênc. Tecnol. Aliment. 2010;30(1):183-87.

18. Deng S, West BJ, Palu AK, Jensen CJ. Phytochemical, Antioxidant and Toxicological Investigation of Morinda citrifolia L. Blossoms, Anal Chem. 2012;2012:15.

19. Wei GJ, ChiTH, An SH. Analysis of Volatile Compounds in Noni Fruit (Morinda citrifolia L.) Juice by Steam Distillation-Extraction and Solid Phase Microextraction Coupled with GC/AED and GC/MS. Journal of Food and Drug Analysis. $2011 ; 19(1): 33-9$

20. Bussmann RW, Lothar H, Athanassios G Jutta O, Toni MK, Feng X. Anthraquinone Content in Noni (Morinda citrifolia L.). Evidence Based Complementary and Alternative Medicine. 2013; vol 2013,1-5

21. Bramorski A, Adriana RC, Chaiana PM, Joseane T, Tatiana M, Andréa de ASC. Total polyphenol content and antioxidant activity of commercial Noni (Morinda citrifolia L.) juice and its components. Brazilian Journal of Pharmaceutical Sciences. 2010;46(4):651-56. 
22. Dussossoy E, Brat P, Bony E, Boudard F, Poucheret P, Mertz C. Characterization, anti-oxidative and anti-inflammatory effects of Costa Rican noni juice (Morinda citrifolia L.). J Ethnopharmacol. 2011;133(1):108-15.

23. Hiramatsu T, Imoto M, Koyano T, Umezawa K. Induction of normal phenotypes in ras transformed cells by damnacanthal for Morinda citrifolia. Cancer Lett. 1993;73(2):161-6.

24. Aziz MYA, Abdul RO, Tamilselvan S, Swee KY, Wan YH, Ismail NH. Damnacanthal is a potent inducer of apoptosis with anticancer activity by stimulating p53 and p21 genes in MCF7 breast cancer. Oncology Letters. 2014;7(5):1479-84.

25. Vilas JAG, Ana RQ, Miguel AM. Damnacanthal, a noni anthraquinone, inhibits c-Met and is a potent antitumor compound against Hep G2 human hepatocellular carcinoma cells. Sci Rep. 2015;5,(8021), 1-9.

26. Hiwasaa T, Yoshiko A, Zheng C, Kazuko K, Kazuo U, Hisao I. Stimulation of ultraviolet-induced apoptosis of human fibroblast UV-1 cells by tyrosine kinase inhibitor. FEBS Lett. 1999;444(1-2):173-6.

27. Anonymous (2015a). EGCg in Green Tea Found to Limit Activity of Breast Cancer Cells. Asia Pacific Bio Tech News. 1998;2(35):562.

28. Hornick CA, Myers A, Sadowska KH, Anthony CT, Woltering EA. Inhibition of angiogenic initiation and disruption of newly established human vascular networks by juice from Morindacitrifolia (noni). Angiogenesis. 2003;6(2):143-9.

29. Hirazumi A, Furusawa E. An immunomodulatory polysaccharide-rich substance from the fruit juice of Morinda citrifolia (noni) with antitumour activity. Phytotherapic Research.1999;13(5):380-87.

30. Liu JM, Haroun BF, Boisson VC. Analysis of the in vitro inhibition of mammary adenocarcinoma cell adhesion by sulphated polysaccharides. Anticancer Research. 2000;20(5A):3265-71.

31. Su BN, Pawlus AD, Jung HA, KellerWJ, McLaughlin JL, Kinghorn AD. Chemical constituents of fruits of Morinda citrifolia (noni) and their antioxidant activity. J Nat Prod. 2005;68(4):592-95.

32. Wang MY, Su C. Cancer preventive effect of Morinda citrifolia (Noni). Ann NY Acad Sci. 2001;952(1):161-8.

33. Sun ZJ, Chen G, Hu X, Zhang W, Liu Y, Zhu LX. Activation of PI3K/Akt/IKK alpha/NF-kappa B signaling pathway is required for the apoptosis-evasion in human salivary adenoid cystic carcinoma: its inhibition by quercetin. Apoptosis. 2010;15(7):850-63.

34. Chang TN, Jeng SD, Yi CC, Lee CY, Liao JC, Lee MM. Ameliorative Effects of Scopoletin from Crossostephium chinensis against Inflammation Pain and Its Mechanisms in Mice. Evidence Based Complementary and Alternative Medicine. 2012; vol 2012, 1-10.

35. Sang S, Kan H, Guangming L NanqunZ, Mingfu W, Jhoo JW. Citrifolinin A, a new unusual iridoid with inhibition of activator protein-1 (AP-1) from the leaves of noni (Morinda citrifolia L.). Science Direct. 2001;42(10):1823-5.

36. Hohl RJ. Monoterpenes as regulators of malignant cell proliferation. Adv Exp Med Biol. 1996;401:137-46.

37. Heinonen OP, Demetrius A, Jarmo V, Philip RT, Jussi KH, Anne MH. Prostate cancer and supplementation with alpha-tocopherol and beta-carotene: incidence and mortality in a controlled trial. J Natl Cancer Inst. 1998;90(6):440-46.

38. Wang MY, West BJ, Jensen CJ, Diane N, SU C, Palu AK. Morinda citrifolia (noni): A literature review and recent advances in Noni research. Acta Pharmacol Sin. 2002a;23(12):1127-41.

39. Kim SH, Jun CD, Suk K, Choi BJ, Lim H, Park S. Gallic Acid Inhibits Histamine Release and Pro-inflammatory Cytokine Production in Mast Cells. Toxicol Sci. 2006;91(1):123-31.

40. A.O.A.C. Official Methods of Analysis. Association of Official Analytical Chemist, Wahington, D.C. 1990.

41. Amerine MA, Pangborn RM, Roessler EB. Principles of sensory evaluation of food. Academic Press, New York.1987.

42. Joshi AA, Chilkawar PM, Jadhav BA. Studies on Physico-Chemical Properties of Noni Fruit (Morinda citrifolia) and Preparation of Noni Beverages. Int J Food Sci Nutr Diet. 2012;1(1):3-8

43. Potterat O, Felten RV, Dalsgaard PW, Hamburger M. Identification of TLC Markers and Quantification by HPLC-MS of Various Constituents in Noni Fruit Powder and Commercial Noni-Derived Products. J Agric Food Chem. 2007;55(18):7489-94.

44. Deng S, West BJ, Jensen CJ. A Quantitative Comparison of Phytochemical Components in Global Noni Fruits and Their Commercial Products. Food Chemistry. 2010;122(1):267-70.

45. Lv L, Chen $H, H o C T$, Sang S. Chemical components of the roots of noni (Morinda citrifolia) and their cytotoxic effects. Fitoterapia. 2011;82(4):704-8.

46. Stoner GD, Li S, Claire S, Claudio R, Kristen S, Steven C. Multiple berry types prevent n-nitrosomethylbenzylamine induced esophageal cancer in rats. Pharm Res. 2010;27(6):1138-45.

47. William PC, Tracy LK, Mary PK, Warren GF, Vicki LD. Morinda citrifolia (noni) juice augments mammary gland differentiation and reduces mammary tumor growth in mice expressing the unactivated c-erbB2 transgene. Evidance Based Complement Alternative Med. 2012;2012,1-15.

48. Taskin El, Kadriye AD, Aysegul K, Esma O, Husniye D, Hakan E. Apoptosisinducing effects of Morinda citrifolia L. and doxorubicin on the ehrlich ascites tumor in Balb-c mice. Cell Biochem Funct. 2009;27(8):542-6.
49. Wang MY, Lin P, Gary A, Diane N. Breast cancer prevention with Morinda citrifolia (noni) at the initiation stage. Functional Foods in Health and Disease. 2013;3(6):203-22

50. Nualsanit T, Pleumchitt R, Wandee G, Leea SH, Darunee L, Seung JB. Damnacanthal, A noni component, exhibits anti-tumorigenic activity in human colorectal cancer cells. J Nutr Biochem. 2012:23(8):915-23.

51. Gupta RK, Banerjee A, Pathak S, Sharma C, Singh N. Induction of mitochondrial-mediated apoptosis by Morinda citrifolia (noni) in human cervical cancer cells. Asian Pac J Cancer Prev. 2013;14(1):237.

52. Karamcheti SA, Satyavati D, Subramanian NS, Pradeep HA, Pradeep KC, Deepika PG. Chemoprotective effect of ethanolic extract of Morinda citrifolia against Cisplatin induced nephrotoxicity. The Pharma Innovation. 2014;3(1): 84-91.

53. Kamiya K, Tanaka Y, Endang H, Umar M, Satake T. Chemical constituents of Morinda citrifolia fruits inhibit copper induced low-density lipoprotein oxidation. Journal of Agriculture and Food Chemistry. 2004;52(19):5843-8.

54. Pandy V, Megala N, Zahurin M. Antipsychotic-like activity of noni (Morinda citrifolia Linn.) in mice. BMC Complementary and Alternative Medicine. 2012;12(1):186

55. Weeks BS. Formulations of dietary supplements and herbal extracts for relaxation and anxiolytic action. Relarian Med Sci Monit. 2009;15(11): 256-62.

56. Deng S, West BJ. Antidepressant effects of Noni fruit and its active principals. Asian Journal of Medical Sciences. 2011;3(2):79-83.

57. Muto J, Lee H, Akemi U, Fumiyuki I, Makoto O, Toshio M. Morinda citrifolia fruit reduces stress induced impairment of cognitive function accompanied by vasculature improvement in mice. PhysiolBehav. 2010;101(2):211-7.

58. Harada S, Wakako FH, Kohei K, Yoshiyuki M, Toshiko S, Shogo T. Morinda citrifolia fruit juice prevents ischemic neuronal damage through suppression of the development of post-ischemic glucose intolerance. J Nat Med. 2010;64(4):468-73.

59. Uma G, Maheswari SU. Neuroprotective effects of polyherbal formulation (Indian) on noni scopolamine-induced memory impairment in mice. International Journal of Pharmacy and Pharmaceutical Sciences. 2014;6(1):354-57.

60. Rasal VP, Arulmozhi S, Purnima A, Sridhar Y. Wound healing and antioxidant activities of Morinda citrifolia leaf extract in rats. IJPT. 2008;7(1):49-52.

61. Nayak S, Mengi S. Immunostimulant activity of Noni (Morinda citrifolia) on T and B lymphocytes. Pharm Biol. 2010;48(7);724-31.

62. Wang MY, Diane N, Gary A, Jarakae J, West B. Liver protective effects of Morinda citrifolia (noni). Plant Foods Hum Nutr. 2008;63(2):59-63.

63. Saminathan M, Ram BR, Kuldeep D, Babu LJ, Subramaniyam S, Gopikunte JR Effects of Morinda citrifolia (noni) fruit juice on antioxidant, hematological and biochemical parameters in N-Methyl-N-Nitrosourea (NMU) induced mammary carcinogenesis in sprague-dawley rats. International Journal of Pharmacology. 2014;10(2):109-19.

64. Zin ZM, Hamid AA, Osman A. Antioxidative activity of extracts from Mengkudu (Morinda citrifolia L.) root, fruit and leaf. Food Chemistry. 2002;78(2):227-31.

65. Mckoy MG, Everton AT, Oswald RS. Preliminary Investigation of the antiinflammatory properties of an aqueous extract from Morinda citrifolia (noni). Proc West Pharmacol Soc. 2002;2002(45):76-8.

66. Su C, Wang MY, Nowicki D Jensen J, Anderson G. Selective COX- 2 inhibition of Morinda citrifolia (noni) in-vitro. The Proceedings of the eicosanoids and other bioactive lipids in cancer, inflammation and related disease. $7^{\text {th }}$ Ann Conf. 2001;14-7.

67. Mandukhail SR, Nauman A, Anwarul HG. Studies on anti-dyslipidemic effects of Morinda citrifolia (noni) fruit, leaves and root extracts. Lipids in Health Dis. 2010;9(88):1-6.

68. Pazos DC, Jiménez FE, Garduño L, López VE, Cruz MC. Hypolipidemic effect of seed oil of noni (Morinda citrifolia). Nat Prod Commun. 2011;6(7):1005-8.

69. Pu HF, Wei JH, Tseng WM, Wang SW, Liu YW, Doong ML. Effects of Juice from Morinda citrifolia (Noni) on gastric emptying in male rats. Chin J Physiol. 2004:47(4):169-74.

70. Mahattanadul S, Ridtitid W, Nima S, Phdoongsombut N, Ratanasuwon P, Kasiwong S. Effects of Morinda citrifolia aqueous fruit extract and its biomarker scopoletin on reflux esophagitis and gastric ulcer in rats. Journal of Ethnopharmacology. 2011;134(2):243-50.

71. Usha R, Sangeetha S, Palaniswamy M. Antimicrobial activity of a rarely known species, Morinda citrifoliaL. Ethnobotanical Leaflets. 2010;14(2012): 306-11.

72. Jainkittivong A, Butsarakamruha T, Langlais RP. Antifungal activity of Morinda citrifolia fruit extract against Candida albicans. Oral Surg Oral Med Oral Pathol Oral Radiol Endod. 2009;108(3):394-8.

73. Umezawa K. Isolation of 1-methoxy-2-foremyl-3-hydroxyanthraquinone from $M$ citrifolia and neoplasm inhibitors containing the same. Japan Kokai Tokyo Koho JP. 1992;6(87):736 (94-87,736) 1992; Appl: 92-264-311 07.

74. Nayak BS, Julien RM, Godwin I, AndrewA. Hypoglycemic and hepatoprotective activity of fermented fruit juice of Morinda citrifolia (Noni) in diabetic rats. Evidence Based Complementary and Alternative Medicine. 2011; 2011, 1-5.

75. Joseph B. Pride publishing, noni: Polynesia's natural pharmacy. 1997; P 13.

76. Gilani AH, Mandukhail SR, Javeid I, Masoom Y, Nauman A, Aslam K. Antispas- 
modic and vasodilator activities of Morinda citrifolia root extract are mediated through blockade of voltage dependent calcium channels. BMC J Altern Complement Med. 2010;10(2):1-9.

77. Wu YB, Cheng JZ, Lu PQ, Sun LN, Ting H, Lei J. Antiosteoporotic activity of anthraquinones from Morinda officinalis on osteoblasts and osteoclasts. Molecules Journal. 2009;14(1):573-83.

78. Palu AK, Kim AH, West BJ, Deng S, Jensen J, White L. The effects of Morindacitrifolia L. (noni) on the immune system: Its molecular mechanisms of action. Journal of Ethnopharmacology. 2008a;115(3):502-6.

79. Buranakarl C, Kalandakanond TS, Pondeenana S. Renal catecholamine contents in doxorubicin-treated rats receiving Morinda citrifolia (noni) juice. Thai Journal of Physiological Sciences. 2008;20(2):2.

80. Bao L, Luping Q, Lei Liu. Anthraquinone compounds from Morinda officinalis inhibit osteoclastic bone resorption in-vitro. ChemBiol Interact. 2011;194 (2-3):97-105.

81. West BJ, Leland DW, Jensen CJ, Palu AK. A double-blind clinical safety study of Noni fruit juice. Pacific Health Dialog. 2009a;15(2):21-32.

82. Wang MY, Lin P, Lutfiyya MN, Henley E, Weidenbacher-Hoper V, Anderson G. Morinda citrifolia (noni) reduces cancer risk in current smokers by decreasing aromatic DNA adducts. Nutrition and cancer. 2009a;61(5):634-9.

83. Wang MY, Cheerva A, Su C, Jensen J, Nowicki D, Anderson G. Protective effects of Morinda citrifolia (noni) on plasma SAR and LPO in current smokers. Society for Free Radical Research International. 2002b;7(16-20):729-34.

84. Wang MY, Lutfiyya MN, Vicki WH, Anderson G, Su CX, West BJ. Antioxidant activity of noni juice in heavy smokers. Chemistry Central Journal. 2009b;3(13): $1-5$.

85. Wang MY, Lin P, Lutfiyya N, Vicki WH, Joella W, Anderson G. Morinda citrifolia (noni) fruit juice lowers cancer risk in current smokers by reducing Malondialdehyde (MDA)-DNA adducts. AARC Annual Meeting. Los Angel CA 2007;67:14-18.

86. Wang MY, Henley E, Jeanette $N$, Alexandra $C$, Swedish $A H$, Jensen J. The Effects of Morinda citrifolia (noni) fruit juice on serum cholesterol and triglyceride in current smokers. American Heart Association journal. 2006;113:301-81.

87. Wong DK. Are immune responses pivotal to cancer patient's long term survival? Two clinical case-study reports on the effects of Morinda citrifolia (Noni). Hawaii Med J. 2004;63(6):182-84.

88. Palu AK, Raevonne AS, West BJ, Norman K, Jensen J. The effects of Morinda citrifolia L. Noni on High Blood Pressure: A Mechanistic Investigation and Case Study. Functional Food and Health. 2008c;993(39):446-53.

89. Palu AK, Ashley NB, West BJ, Jensen JC, Shixin D, Norman K. The cholesterol lowering mechanisms of Morinda citrifoliaL. (noni): A mechanistic investigation and case study involving hypercholesterolemia nonsmoking subjects. American Chemical Society. 2009;237(3-3):22-6.

90. West BJ, Sixin D, Afa KP, Jensen CJ. Morinda citrifolia Linn. (Rubiaceae) leaf extracts mitigate UVB-induced erythema. J Nat Med. 2009b;63(3):351-4.

91. West BJ, Rachel AS. Efficacy of a Morinda citrifolia Based Skin Care Regimen. Current Research Journal of Biological Sciences. 2012;4(3):310-14

92. Wang MY, Lin P, Vicki WH, Shixin D, Anderson G, West BJ. Noni juice improves serum lipid profiles and other risk markers in cigarette smokers. The Scientific World. 2012; vol. 2012, 1-8.
93. Kumar GS. The effect of Noni (Morinda citrifolia L.) in type 2 diabetes mellitus in inadequately controlled patients. Noni Cli Res J. 2007;1(1-2):20-4.

94. Wang MY, Lutfiyya NM, Vicki WH, Lin P, Martin SL, Anderson G. Morinda citrifolia $L$. (noni) improves the quality of life in adults with osteoarthritis. Functional Foods in Health and Disease. 2011;1(2):1-21.

95. Langford J, Doughty A, Wang M, Clayton L, Babich M. Effects of Morinda citrifolia on quality of life and auditory function in postmenopausal women. J Altern Complement Med. 2004;10510(5):737-9.

96. Olsen A. A brief summary of Morinda's human clinical trials.2010. Available at:https://morinda.com/en-us/news/316871, Accessed on 16 June 2014

97. Palu AK, Seifulla RD, Brett JW. Morinda citrifolia L. (noni) improves athlete endurance: Its mechanisms of action. Journal of Medicinal Plants Research. 2008b;2(7):154-8

98. Glang J, Wolfgang F, Johannes W. Effect of Morinda citrifolia L. fruit juice on gingivitis/periodontitis. Modern Research in Inflammation. 2013;2(2013):21-7.

99. Mueller BA, Meri KS, Kevin MS, Kathleen AP. Noni juice (Morinda citrifolia): hidden potential for hyperkalemia?. Am J Kidney Dis. 2000;35(2):310-2.

100. Pawlus A, Su BN, Kinghorn A. Noni (Morinda citrifolia). In: Coates P, Blackman M, Cragg G, et al., eds. Encyclopedia of dietary Supplements. New York, NY: Marcel Dekker, 2005; 1-8.

101. Bresson JL, Albert F, Marina H, Karin H, Hannu K, Pagona L. Scientific Opinion of the Panel on Dietetic Products Nutrition and Allergies on a request from the European Commission on the safety of 'Morinda citrifolia (noni) fruit puree and concentrate' as a novel food ingredient. The EFSA Journal. 2009;998:1-6.

102. Elkins RMH. Hawaiian noni (M. citrifolia) Prize Herb of Hawaii and the South Pacific. Woodland Publishing, Utah. 1998

103. Wei X, Song QS, Zhang HJ, Guo SP. Antimicrobial anthraquinones from Morinda angustifolia. Fitoterapia. 2008;79(7):501-4.

104. Ross IA. Medicinal plants of the world, chemical constituents, traditional and modern medicinal uses. Humana Press, New Jersey. 2005; vol. 3.

105. Inoue $\mathrm{K}$, Nayeshiro $\mathrm{H}$, Inouye $\mathrm{H}$. Anthraquinones in cell suspension culture of Morinda citrifolia. Phytochemistry. 1981;20(7):1693-700.

106. Cardon D. Le Monde des Teintures Naturelles. Belin, Paris. Chemistry. 2003;49(7):4478-81.

107. Bushnell OA, Mitsuno F, Takashit M. The antibacterial properties of some plants found in Hawaii. Pacific Science. 1950;4(7):167-83.

108. Chunhieng MT. Developement de nouveaux aliments santé tropicale: application a' la noix du Bre' silBertholettiaexcelsaet au fruit de Cambodg Morindacitrifolia. Ph.D. Thesis, INPL, France. 2003.

109. Sang S, Wang M, Ken H, Guangming L, Zigang D, Vladimir B. Chemical components in Noni fruits and leaves (Morinda citrifolia L.). In: Ho CT, Zheng QY (Eds.), Quality management of nutraceuticals. ASC Symposium Series 803 American Chemistry Society. 2002;134-50.

110. Farine JP, Legal L, MoreteauB, Quere JLL. Volatile components of ripe fruit of Morinda citrifolia and their effects on Drosophila. Phytochemistry. 1996;41(2):433-8

111. Bui AKT, Antony B, Filomena P. Polysaccharide composition of the fruit juice of M. citrifolia (Noni). Phytochemistry. 2006;67(12):1271-5. 


\section{PICTORIAL ABSTRACT}

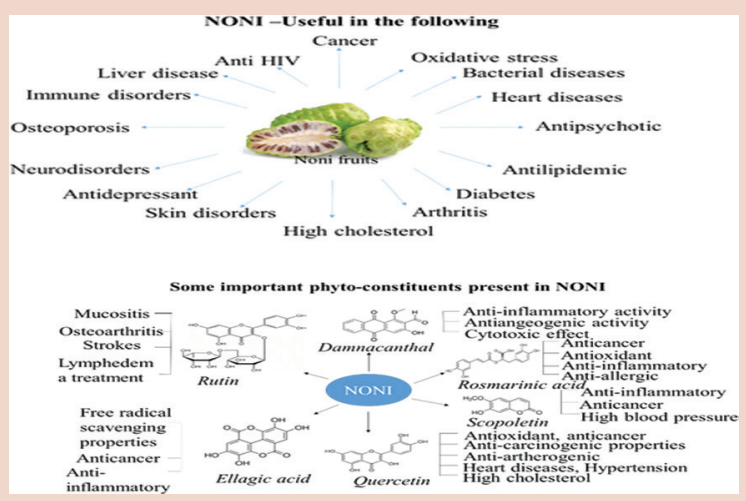

\section{ABOUT AUTHORS}

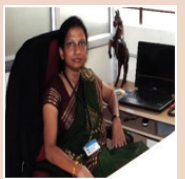

Dr. S.N. Manjula: Completed M. Pharm, in Pharmacology in the year 2001 from Govt. College of Pharmacy, Bangalore. She was awarded with Ph.D. in 2010 from Manipal University, Manipal. Presently Dr. S.N. Manjula is working as an Assistant professor and Head, Dept. of Pharmacology at JSS College of Pharmacy, Mysore. She has been working here since 2001. She received a research fellowship from DST under Women Scientist Scheme-A for her thesis work entitled "Evaluation of anticancer activity of some novel benzothiazole analogs in vitro and in vivo". She has also got grants from VGST, Govt. of Karnataka and AICTE New Delhi for creating infrastructure and development of research facilities. Her primary area of research is cancer and other areas of research are inflammation, chemoprevention, chemoprotection and diabetes. Currently she is involved in screening of novel EGFR inhibitors and several herbs for their in-vitro and in-vivo antitumor activity. She has guided 25 Postgraduate students and currently Guiding 4 PhD scholars. She has more than 20 research papers to her credit in various national and international journals, has presented several papers in national and international seminars/conferences.

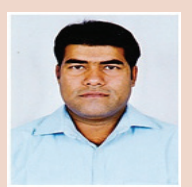

Mr. Mohammad Ali, Ph.D.: Student at JSS College of Pharmacy, Mysore. He completed B. Pharm from JSS College Pharmacy Mysore in the year 2006 and M. Pharm in pharmacy practice from Annamalai University in the year 2009. HisPh.D. research focused on the "Evaluation of chemoprotective effect of Morinda citrifolia (Noni) juice against anticancer drugs induced toxicity through preclinical and clinical studies". 